\title{
Trend and Levels of Women Empowerment in Nigeria
}

\author{
ACHA, CHIGOZIE KELECHI* \\ DEPARTMENT OF STATISTICS, MICHEAL OKPARA UNIVERSITY OF AGRICULTURE, UMUDIKE, ABIA STATE, \\ NIGERIA \\ *Corresponding author: specialgozie@yahoo.com
}

Received October 20, 2014; Revised November 07, 2014; Accepted December 15, 2014

\begin{abstract}
Women empowerment has become major factor in economic development and is increasingly at the core of countries' competitiveness in the global economy. The main objective of this paper is to ascertain the trend and level of women empowerment in Nigeria by 2015. Secondary data from Nigeria Demographic and Health Survey (NDHS), Nigeria Demographic and Education Survey (NDES), and National Population Commission (NPC) were used. Employment, education and literacy rate were adopted as measures of women empowerment. An overview of the relationship between women's level of education and other background characteristics was carried out. The results showed that men are more likely than women to have some education. Over 40 percent of men are literate compared to 13 percent of women, which is similar to the results obtained from variables like occupation, agriculture, etc. Employment is one source of empowerment for women but unfortunately it is difficult to measure their employment status because the informal sectors are not reported. However, the data on hand indicates, for instance, that women and men currently employed in the North West are 46 and 54 percent respectively. Also, the employment rate of men and women in urban area are of the ratio 42:37 percent while the employment ratio of men to women in the rural area is 63:58. The study also hints that employment, education and literacy rate of women are strong determinants of economic growth and they should not be neglected as the nation works toward attaining vision 2020 goals.
\end{abstract}

Keywords: education, employment, empowerment, equality, economy

Cite This Article: ACHA, CHIGOZIE KELECHI, "Trend and Levels of Women Empowerment in Nigeria." American Journal of Applied Mathematics and Statistics, vol. 2, no. 6 (2014): 402-408. doi: 10.12691/ajams-2-6-8.

\section{Introduction}

Western-style education was introduced in Nigeria by the missionaries in the mid-nineteenth century. Progress in education was slow but steady throughout the colonial era until the end of World War II. By 1950 the country had developed a three-tier system of primary, secondary, and higher education based on the British model of wide participation at the bottom, sorting into academic and vocational training at the secondary level, and higher education. Education for the purpose of this study is the act or process of imparting or acquiring general knowledge, developing the powers of reasoning and judgment, and generally of preparing oneself or others intellectually for mature life. Therefore, educating women is the act or process of imparting particular knowledge or skills on women.

Knowledge accumulation and application have become major factors in economic development and are increasingly at the core of many countries' competitive advantage in the global economy. For economic and other social and psychological reasons, most developing countries are currently witnessing a massive influx of women into workforce. One sure way of empowering women and reducing gender inequality in today's fast changing world, especially in a developing society like
Nigeria, is by getting more women educated and employed. Women education is therefore necessary for developing countries especially Nigeria to; experience higher economic growth, reduce incidence of poverty, increase average wage, increase share of trade in gross domestic product, and improve health. This leads to the major objective of this paper which is to ascertain the trend and level of women empowerment status. Employment, education and literacy rate were used to measure women empowerment. A secondary data from various surveys in Nigeria were used. To achieve this objective which this paper has set for itself, the next section examines the literature of women population, the third section describes the method to be adopted in data analysis. In the fourth section, data were analyzed and interpreted. The paper is summarized, conclusion is drawn and recommendations are made in the fifth section.

\section{Literature Review}

According to Acha (2009), women empowerment is a measure of sustainable good governance in Nigeria. No proper development planning can be successfully made without the use of proper social and economic planning. This has always remained a challenge and cannot be conquered except the women population, their welfare and contributions are significantly put in place. Aderant, 
(2002), Annekova (2001), Iheduru (2002), Lewis (2006), Mansor (2005), Peters (2010, 2011) have confirmed that women development is very useful in the areas of revenue allocation, determination of per capital income, the labour force etc.

To foster the above position, there should be improvements on women's access to basic economic resources such as land, labour-saving machines (such as tractors), food processing machines, financial capital and other agricultural innovations such as improved seedlings, pesticides, herbicides, fertilizers et cetera. To ensure proper utilization of these facilities, technical services as well as market information should be made available to women farmers among others; see Ayu (1991, 1992), Wushish (1993), Arene (1993), Mazrui (1991), Anderson, et. al. (2008), Bilimoria, \& Liang, (2012), Burke, \& Major, (2014), Debebe (2011), Debebe \& Reinert (2014), Ely, et. al. (2011), Hopkins, et. al. (2008), Jarvis, et. al (2013). It boils down to the need for women to be literate, educated and be employed in Nigeria and other countries. The population projection result by Acha (2014) showed that there is exponential growth in women population and without commensurate growth in their literacy rates, education attainment and employment the third millennium development goal will seem a mirage Agbalajobi, (2010) and Ekundayo \& Ama, (2014). This leads to the importance of this paper which is to ascertain the trend and level of women empowerment status in Nigeria.

\section{Methodology}

The study will be based on descriptive research method, as well; inferential statistics will be employed to enable the ascertainment of the trend and level of women empowerment in Nigeria.

\section{Data Analysis and Interpretation of Results}

\subsection{Employment Status by Background Characteristics}

Table 1. Percentage Distribution of Women and Men by Employment Status According to Background Characteristic

\begin{tabular}{|c|c|c|c|c|c|c|}
\hline Characteristics & \multicolumn{3}{|c|}{ Women } & \multicolumn{3}{|c|}{ Men } \\
\hline Age & $\begin{array}{c}\text { Currently } \\
\text { employed }^{1}\end{array}$ & $\begin{array}{c}\text { Not currently } \\
\text { employed }\end{array}$ & Not employed & $\begin{array}{c}\text { Currently } \\
\text { employed }^{1}\end{array}$ & $\begin{array}{c}\text { Not currently } \\
\text { employed }\end{array}$ & Not employed \\
\hline $15-19$ & 26.1 & 4.2 & 71.6 & 44.8 & 3.7 & 51.6 \\
\hline $25-29$ & 65.0 & 3.4 & 31.5 & 85.7 & 2.1 & 12.1 \\
\hline $30-34$ & 73.1 & 4.0 & 22.7 & 94.9 & 1.2 & 3.8 \\
\hline $35-39$ & 77.6 & 3.4 & 18.8 & 98.0 & 0.8 & 1.2 \\
\hline $40-44$ & 77.2 & 4.2 & 18.4 & 98.1 & 0.8 & 1.1 \\
\hline $45-49$ & 77.4 & 5.8 & 16.7 & 98.4 & 0.3 & 1.4 \\
\hline \multicolumn{7}{|l|}{ Residence } \\
\hline Urban & 59.7 & 2.4 & 37.7 & 75.4 & 2.0 & 22.5 \\
\hline Rural & 58.8 & 4.2 & 36.8 & 82.8 & 1.9 & 15.3 \\
\hline \multicolumn{7}{|l|}{ Zone } \\
\hline North Central & 62.8 & 3.2 & 33.9 & 84.9 & 2.6 & 12.5 \\
\hline North East & 57.1 & 4.1 & 38.6 & 90.8 & 1.6 & 7.6 \\
\hline North West & 46.0 & 7.2 & 46.6 & 86.4 & 1.7 & 11.8 \\
\hline South South & 63.9 & 2.4 & 33.5 & 69.4 & 3.5 & 27.0 \\
\hline South West & 69.9 & 1.4 & 28.7 & 75.9 & 1.0 & 23.1 \\
\hline \multicolumn{7}{|l|}{ Education } \\
\hline No education & 56.8 & 5.4 & 37.5 & 97.3 & 0.9 & 1.9 \\
\hline Primary & 73.1 & 3.4 & 23.3 & 90.9 & 1.3 & 7.7 \\
\hline Secondary & 52.9 & 2.2 & 44.8 & 70.1 & 2.5 & 27.4 \\
\hline More than secondary & 62.5 & 1.9 & 35.6 & 74.6 & 2.4 & 23.0 \\
\hline
\end{tabular}

Source: Nigeria Demographic and Health Survey 2008

Employment is one source of empowerment for women, given that it enables them exercise control over their own income and by extension their lives. Table 1 shows significant difference in employment of men and women who reside in the urban areas (75-60 percent and 83-58 percent respectively). Looking it from the perspective of the numbers not employed one sees for example that unemployment rate for women between the ages of 45-49 is 5.8 percent while that of men is 0.3 percent. Even employment rates of men that are not educated are higher than those of women, that is, 97.3: 56.8.

The four plots in Figure 1 depict the pictorial aspect of the background characteristics for age-specific rate and education by sex in Table 1 . It shows that forty percent of women have no education and only 8.5 percent had higher education. The different age cohorts 15-19 and 45-49 increase from 29 percent to 64 percent respectively. It also shows the total percentage distribution of women respondents' age specific by highest level of women educational attainment.

Table 2. Employment According to Age/Sex

\begin{tabular}{|c|c|c|}
\hline Characteristics & \multicolumn{2}{|c|}{ Employment Rate by Sex. } \\
\hline Age & Men & Women \\
\hline $15-19$ & 24.9 & 18.3 \\
\hline $20-24$ & 57.5 & 35.0 \\
\hline $25-29$ & 79.8 & 43.4 \\
\hline $30-34$ & 88.8 & 46.1 \\
\hline $35-39$ & 91.5 & 53.0 \\
\hline $40-44$ & 91.1 & 50.6 \\
\hline $45-49$ & 92.1 & 59.1 \\
\hline ALL AGES (MEAN) & 75.1 & 43.6 \\
\hline
\end{tabular}

Source: Nigeria, 1991 population census. 

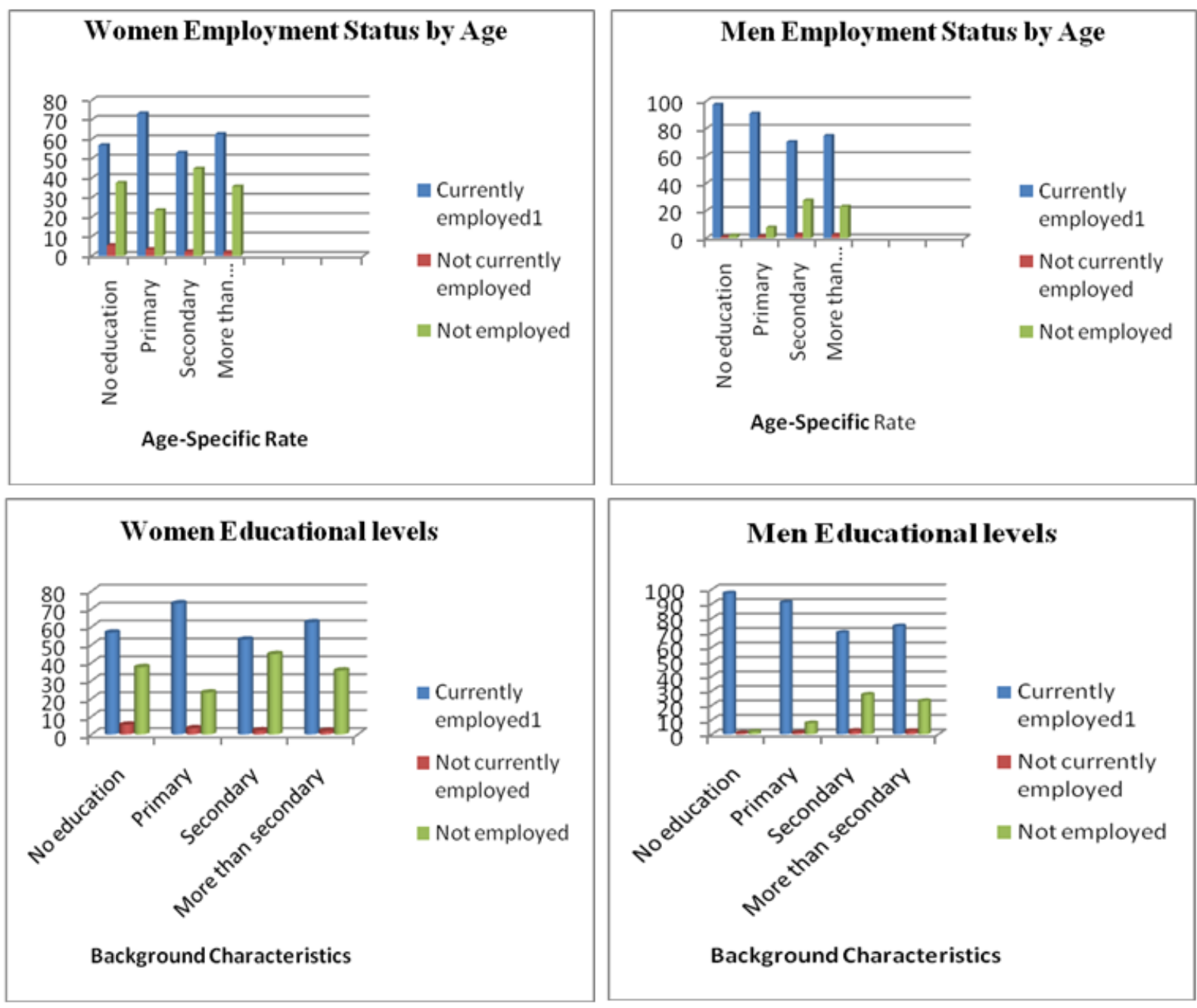

Figure 1. Percentage Distribution of women and Men in 2008 NDHS

The employment rate shows different patterns for men and women. Generally, the age-specific participation rate for men (75.1 percent) is higher than that of women (43.6 percent). Specifically, for example, 92 percent for men and 59 percent for women in age group 45-49 years are employed. See Figure 2, for the graphical view of Table 2.

Table 3. Total Percentage Distribution of Women Respondents Age Specific by Highest Level of Women Educational Attainment

\begin{tabular}{|c|c|c|c|c|}
\hline Age & No Education & Primary & Secondary & Higher \\
\hline $15-49$ & 40.1 & 17.8 & 33.6 & 8.5 \\
\hline
\end{tabular}

Source: Sentinel Survey 2007, Pg. 20.

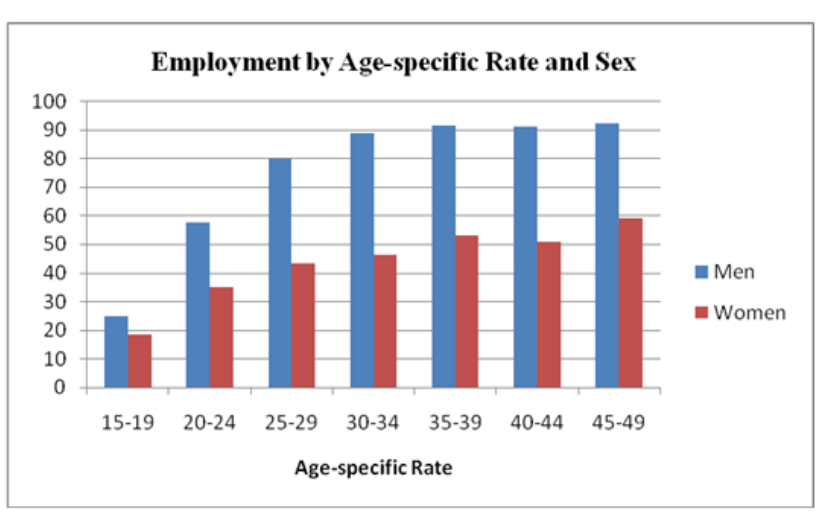

Figure 2. Employment according to Age/Sex -1991 population census

Table 3, shows that forty percent of women have no education and only 8.5 percent had higher education. The different age cohorts 15-19 and 45-49 increase from 29 percent to 64 percent respectively. Figure 3 shows the total percentage distribution of women respondents' age specific by highest level of women educational attainment. It also shows that number of women that are not educated is still very high.

\section{Women 15 -49 Years}

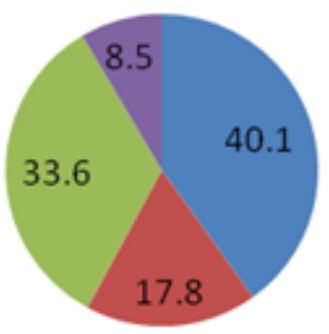

No

Education

- Primary

- Secondary

Figure 3. Age Specific Educational Attainment by Women 
Table 4. Women Educational Attainment by Background Characteristics of Age-Sex specific in NDHS 2008

\begin{tabular}{|c|c|c|c|c|c|c|c|c|}
\hline \multirow[t]{2}{*}{ Characteristics } & \multicolumn{8}{|c|}{ Percentage distribution of men and women age 15-49 by highest level of schooling attended. } \\
\hline & \multicolumn{4}{|c|}{ Women } & \multicolumn{4}{|c|}{ Men } \\
\hline Age & $\begin{array}{c}\text { No } \\
\text { education }\end{array}$ & $\begin{array}{c}\text { Completed } \\
\text { primary }\end{array}$ & $\begin{array}{l}\text { Completed } \\
\text { secondary }\end{array}$ & $\begin{array}{l}\text { More than } \\
\text { secondary }\end{array}$ & $\begin{array}{c}\text { No } \\
\text { education }\end{array}$ & $\begin{array}{c}\text { Completed } \\
\text { primary }\end{array}$ & $\begin{array}{l}\text { Completed } \\
\text { secondary }\end{array}$ & $\begin{array}{l}\text { More than } \\
\text { secondary }\end{array}$ \\
\hline $15-24$ & 27.3 & 9.3 & 20.4 & 5.8 & 13.3 & 8.8 & 25.8 & 7.0 \\
\hline $25-29$ & 34.1 & 14.6 & 21.1 & 12.4 & 17.8 & 13.9 & 30.7 & 20.3 \\
\hline $30-34$ & 37.6 & 15.9 & 17.8 & 12.2 & 20.3 & 17.9 & 26.1 & 19.1 \\
\hline $35-39$ & 38.3 & 19.4 & 14.4 & 10.6 & 21.6 & 21.8 & 23.8 & 16.9 \\
\hline $40-44$ & 46.3 & 17.1 & 11.7 & 9.1 & 35.2 & 21.3 & 22.7 & 16.9 \\
\hline $45-49$ & 59.1 & 14.8 & 6.8 & 6.8 & 29.2 & 21.8 & 18.3 & 17.3 \\
\hline \multicolumn{9}{|l|}{ Residence } \\
\hline Urban & 16.5 & 12.8 & 28.3 & 17.5 & 7.5 & 11.3 & 33.8 & 23.4 \\
\hline Rural & 46.5 & 14.0 & 11.5 & 4.1 & 25.7 & 17.4 & 20.5 & 8.8 \\
\hline \multicolumn{9}{|l|}{ Zone } \\
\hline North Central & 35.5 & 16.8 & 12.9 & 8.0 & 15.4 & 15.0 & 23.4 & 14.3 \\
\hline North East & 68.1 & 8.5 & 5.0 & 2.2 & 45.0 & 11.1 & 11.3 & 7.5 \\
\hline North West & 74.2 & 8.1 & 5.3 & 2.5 & 40.7 & 17.4 & 13.6 & 10.0 \\
\hline South East & 6.3 & 15.3 & 28.6 & 13.0 & 0.9 & 23.0 & 30.1 & 14.1 \\
\hline South South & 6.0 & 17.7 & 26.1 & 12.2 & 2.3 & 13.4 & 34.5 & 16.5 \\
\hline South West & 12.0 & 16.7 & 29.6 & 16.2 & 5.2 & 12.5 & 38.3 & 21.2 \\
\hline
\end{tabular}

Source: Nigeria Demographic and Education Survey 2008

The result in Table 4 shows that men are more likely than women to have some education. For example, more than twice as many men age $45-49$ as women age $15-24$ reported that they have no education (29 versus 59 percent and 13 versus 27 respectively). The median for men in rural area is 6 years while for women is 3 years. Therefore, the overall median years of school completed for men age $115-49$ is 9 years while for women is 6 years of the same age. A similar pattern is observed in zones.

\subsection{Literacy Rate by Age, Sex and Rural- Urban residence}

Table 5. Trend and Level in Age-Sex Specific Literacy Rate 1991-2013

\begin{tabular}{|c|c|c|c|c|c|c|c|c|c|c|c|c|c|c|c|}
\hline \multirow[b]{3}{*}{$\begin{array}{c}\text { Characteris } \\
\text { tic }\end{array}$} & \multicolumn{15}{|c|}{ Age-sex literacy rates by various surveys. } \\
\hline & \multicolumn{8}{|c|}{ Women } & \multicolumn{7}{|c|}{ Men } \\
\hline & $\begin{array}{c}\text { Cens } \\
\text { us } \\
1991\end{array}$ & $\begin{array}{c}\text { NDH } \\
\text { S } \\
2003\end{array}$ & $\begin{array}{c}\text { NDE } \\
\text { S } \\
2004\end{array}$ & $\begin{array}{c}\text { Cens } \\
\text { us } \\
2006\end{array}$ & $\begin{array}{c}\text { Sentin } \\
\text { el } \\
2007\end{array}$ & $\begin{array}{c}\text { NDH } \\
\text { S } \\
2008\end{array}$ & $\begin{array}{c}\mathrm{NDH} \\
\mathrm{S} \\
2011\end{array}$ & $\begin{array}{c}\text { NDH } \\
\text { S } \\
2013\end{array}$ & $\begin{array}{c}\text { Cens } \\
\text { us } \\
1991\end{array}$ & $\begin{array}{c}\text { NDH } \\
\text { S } \\
2003\end{array}$ & $\begin{array}{c}\text { NDH } \\
\text { S } \\
2004\end{array}$ & $\begin{array}{c}\text { Cens } \\
\text { us } \\
2006\end{array}$ & $\begin{array}{c}\text { NDH } \\
\text { S } \\
2008\end{array}$ & $\begin{array}{c}\text { NDH } \\
\text { S } \\
2011\end{array}$ & $\begin{array}{c}\mathrm{NDH} \\
\mathrm{S} \\
2013\end{array}$ \\
\hline $15-19$ & 67.9 & 61.3 & 69.9 & 67.5 & 61.3 & 67.3 & 66.7 & 65.4 & 82.6 & 79.2 & 98.0 & 85.5 & 81.7 & 87.3 & 82.3 \\
\hline $20-24$ & 36.5 & 56.4 & 58.9 & 35.9 & 58.7 & 61.1 & 62.0 & 63.2 & 79.7 & 80.3 & 87.7 & 78.7 & 83.3 & 81.1 & 84.1 \\
\hline $25-29$ & 49.4 & 51.9 & 61.3 & 49.2 & 51.2 & 54.7 & 56.6 & 54.6 & 76.2 & 78.9 & 67.3 & 75.4 & 78.3 & 74.7 & 72.7 \\
\hline $30-34$ & 38.6 & 41.3 & 57.7 & 37.6 & 46.0 & 49.9 & 42.8 & 49.0 & 70.7 & 75.6 & 68.1 & 72.0 & 75.3 & 79.9 & 76.9 \\
\hline $35-39$ & 35.8 & 39.8 & 67.5 & 35.8 & 41.3 & 47.7 & 41.7 & 42.7 & 68.2 & 70.4 & 70.8 & 67.2 & 71.1 & 71.7 & 74.7 \\
\hline $40-44$ & 27.0 & 31.1 & 46.0 & 27.0 & 35.3 & 41.9 & 44.4 & 40.7 & 60.5 & 64.6 & 61.7 & 60.4 & 69.9 & 61.9 & 65.9 \\
\hline $45-49$ & 23.7 & 22.4 & 37.9 & 24.2 & 25.6 & 31.7 & 38.3 & 35.4 & 59.8 & 60.0 & 56.8 & 58.8 & 68.9 & 61.7 & 63.7 \\
\hline
\end{tabular}

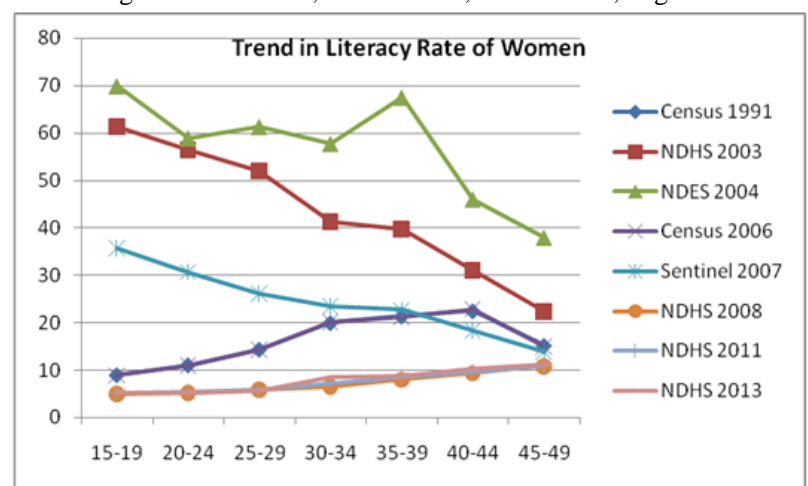

Figure 5. Trend and Level in Age-Sex Specific Literacy Rate for women, 1991-2013

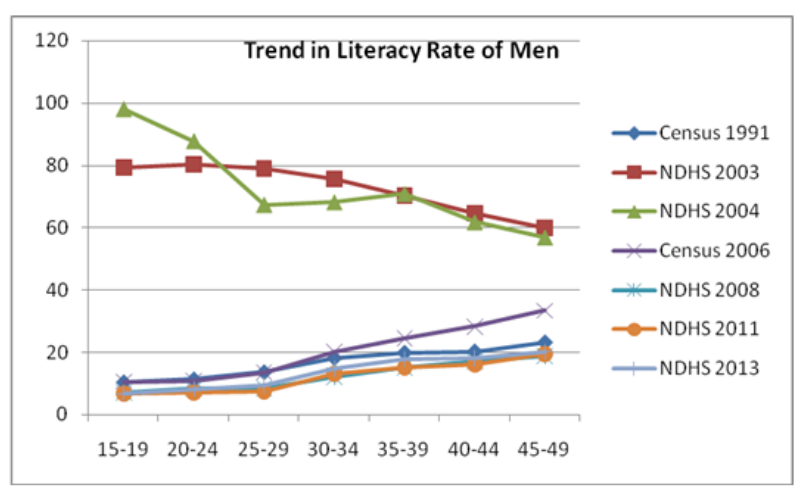

Figure 6. Trend and Level in Age-Sex Specific Literacy Rate for men, 1991-2013

\begin{tabular}{|c|c|c|c|c|c|c|c|c|c|c|c|c|c|c|c|}
\hline \multirow{4}{*}{$\begin{array}{c}\text { Characteris } \\
\text { tic }\end{array}$} & \multicolumn{15}{|c|}{ Age-sex Educational attainment by various surveys. } \\
\hline & \multicolumn{8}{|c|}{ Women } & \multicolumn{7}{|c|}{ Men } \\
\hline & Cens & $\begin{array}{c}\mathrm{NDH} \\
\mathrm{S}\end{array}$ & $\begin{array}{c}\mathrm{NDE} \\
\mathrm{S}\end{array}$ & Cens & Sentin & $\begin{array}{c}\mathrm{NDH} \\
\mathrm{S}\end{array}$ & $\begin{array}{c}\mathrm{NDH} \\
\mathrm{S}\end{array}$ & $\begin{array}{c}\mathrm{NDH} \\
\mathrm{S}\end{array}$ & Cens & $\begin{array}{c}\text { NDH } \\
\text { S }\end{array}$ & $\begin{array}{c}\mathrm{NDH} \\
\mathrm{S}\end{array}$ & Cens & $\begin{array}{c}\mathrm{NDH} \\
\mathrm{S}\end{array}$ & $\begin{array}{c}\mathrm{NDH} \\
\mathrm{S}\end{array}$ & $\begin{array}{c}\mathrm{NDH} \\
\mathrm{S}\end{array}$ \\
\hline & 1991 & 2003 & 2004 & 2006 & 2007 & 2008 & 2011 & 2013 & 1991 & 2003 & 2004 & 2006 & 2008 & 2011 & 2013 \\
\hline $15-19$ & 13.2 & 18.3 & 19.0 & 12.3 & 22.4 & 15.5 & 14.8 & 15.8 & 26.3 & 25.8 & 26.0 & 27.1 & 18.8 & 19.0 & 17.8 \\
\hline $20-24$ & 17.7 & 14.6 & 14.3 & 16.8 & 21.1 & 13.3 & 11.4 & 10.4 & 33.1 & 20.2 & 19.9 & 34.3 & 13.6 & 13.8 & 12.9 \\
\hline $25-29$ & 20.2 & 15.0 & 15.9 & 20.2 & 17.8 & 11.2 & 12.7 & 12.2 & 35.6 & 19.0 & 18.1 & 37.5 & 17.9 & 17.5 & $\begin{array}{l}16.9 \\
\end{array}$ \\
\hline $30-34$ & 21.5 & 14.4 & 14.4 & 20.6 & 14.4 & 12.6 & 11.2 & 10.6 & 37.3 & 16.8 & 15.9 & 38.3 & 22.8 & 21.9 & 21.8 \\
\hline $35-39$ & 35.1 & 14.2 & 15.1 & 34.2 & 11.7 & 16.1 & 15.1 & $\begin{array}{l}19.1 \\
\end{array}$ & 45.3 & 16.8 & $\begin{array}{l}17.9 \\
\end{array}$ & 45.3 & $\begin{array}{l}21.3 \\
\end{array}$ & 21.4 & 22.3 \\
\hline $40-44$ & 29.1 & 15.0 & 14.8 & 28.2 & 9.8 & 16.3 & 14.8 & 16.8 & 58.1 & 17.2 & 16.3 & 59.2 & 21.8 & 21.9 & 20.8 \\
\hline $45-49$ & 13.2 & 12.2 & 11.9 & 12.3 & 20.4 & 5.7 & 13.5 & $\begin{array}{l}15.8 \\
\end{array}$ & 26.3 & 17.2 & $\begin{array}{ll}17.0 \\
\end{array}$ & 26.3 & $\begin{array}{l}18.8 \\
\end{array}$ & $\begin{array}{ll}17.3 \\
\end{array}$ & $\begin{array}{l}18.7 \\
\end{array}$ \\
\hline
\end{tabular}

Source: Nigeria 1991census, NDHS 2003, NDES 2004, Nigeria 2006 census, Sentinel 2007, NDHS 2008, NDHS 2011, NDHS 2013. 


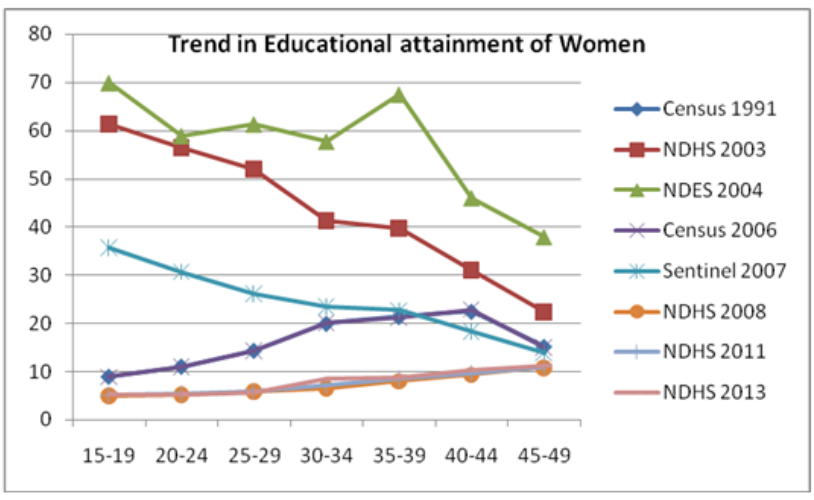

Figure 7. Trend and Level in Age-Sex Specific Educational attainment for women, 1991-2013

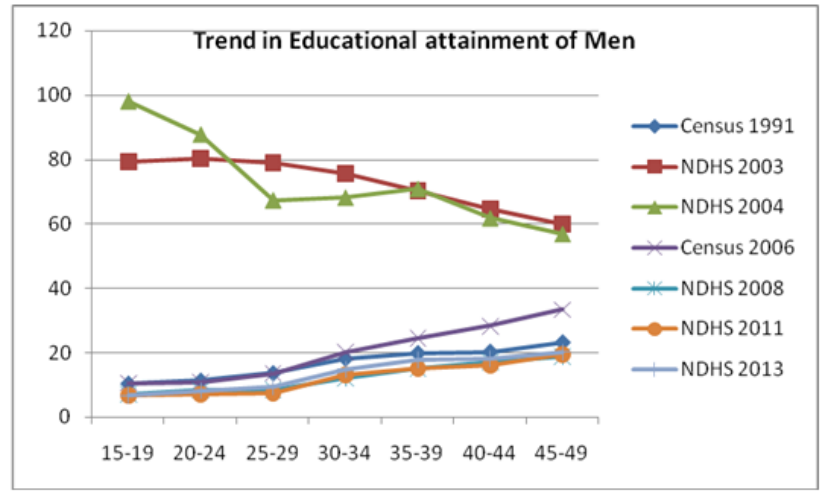

Figure 8. Trend and Level in Age-Sex Specific Educational attainment for men, 1991-2013

\begin{tabular}{|c|c|c|c|c|c|c|c|c|c|c|c|c|c|c|c|}
\hline \multirow{4}{*}{$\begin{array}{c}\text { Characteris } \\
\text { tic }\end{array}$} & \multicolumn{15}{|c|}{ Age-sex employments by various surveys. } \\
\hline & \multicolumn{8}{|c|}{ Women } & \multicolumn{7}{|c|}{ Men } \\
\hline & $\begin{array}{c}\text { Cens } \\
\text { us }\end{array}$ & $\begin{array}{c}\text { NDH } \\
\text { S }\end{array}$ & $\begin{array}{c}\text { NDE } \\
\text { S }\end{array}$ & $\begin{array}{c}\text { Cens } \\
\text { us }\end{array}$ & $\begin{array}{c}\text { Sentin } \\
\text { el }\end{array}$ & $\begin{array}{c}\mathrm{NDH} \\
\mathrm{S}\end{array}$ & $\begin{array}{c}\text { NDH } \\
\text { S }\end{array}$ & $\begin{array}{c}\mathrm{NDH} \\
\mathrm{S}\end{array}$ & $\begin{array}{l}\text { Cens } \\
\text { us }\end{array}$ & $\begin{array}{c}\text { NDH } \\
\text { S }\end{array}$ & $\begin{array}{c}\mathrm{NDH} \\
\mathrm{S}\end{array}$ & $\begin{array}{c}\text { Cens } \\
\text { us }\end{array}$ & $\begin{array}{c}\mathrm{NDH} \\
\mathrm{S}\end{array}$ & $\begin{array}{c}\text { NDH } \\
\text { S }\end{array}$ & $\begin{array}{c}\mathrm{NDH} \\
\mathrm{S}\end{array}$ \\
\hline & 1991 & 2003 & 2004 & 2006 & 2007 & 2008 & 2011 & 2013 & 1991 & 2003 & 2004 & 2006 & 2008 & 2011 & 2013 \\
\hline $15-19$ & 9.0 & 61.3 & 69.9 & 8.9 & 35.8 & 5.0 & 5.2 & 5.3 & 10.4 & 79.2 & 98.0 & 10.6 & 7.0 & 6.7 & 6.8 \\
\hline $20-24$ & 11.1 & 56.4 & 58.9 & 11.0 & 30.7 & 5.3 & 5.5 & 5.4 & 11.3 & 80.3 & 87.7 & 10.8 & 8.2 & 7.2 & 8.3 \\
\hline $25-29$ & 14.4 & 51.9 & 61.3 & 14.3 & 26.1 & 5.9 & 5.8 & 5.7 & 13.6 & 78.9 & 67.3 & 13.6 & 8.5 & 7.5 & 9.5 \\
\hline $30-34$ & 20.0 & 41.3 & 57.7 & 20.2 & 23.4 & 6.6 & 7.2 & 8.5 & 18.1 & 75.6 & 68.1 & 20.1 & 12.0 & 13.0 & 14.9 \\
\hline $35-39$ & 21.4 & $\begin{array}{l}39.8 \\
\end{array}$ & 67.5 & 21.3 & 22.7 & 8.1 & 8.6 & 8.9 & 19.8 & 70.4 & 70.8 & 24.5 & 15.2 & 15.2 & 17.8 \\
\hline $40-44$ & 22.5 & 31.1 & 46.0 & 22.9 & $\begin{array}{l}18.3 \\
\end{array}$ & 9.4 & 9.6 & 10.3 & 20.2 & 64.6 & 61.7 & 28.3 & 17.2 & 16.2 & 18.2 \\
\hline $45-49$ & 15.2 & 22.4 & 37.9 & 15.0 & 13.8 & 10.9 & 11.0 & 11.2 & 23.1 & 60.0 & 56.8 & 33.4 & $\begin{array}{l}18.9 \\
\end{array}$ & 19.5 & 20.2 \\
\hline
\end{tabular}

Source: Nigeria 1991census, NDHS 2003, NDES 2004, Nigeria 2006 census, Sentinel 2007, NDHS 2008, NDHS 2011, NDHS 2013

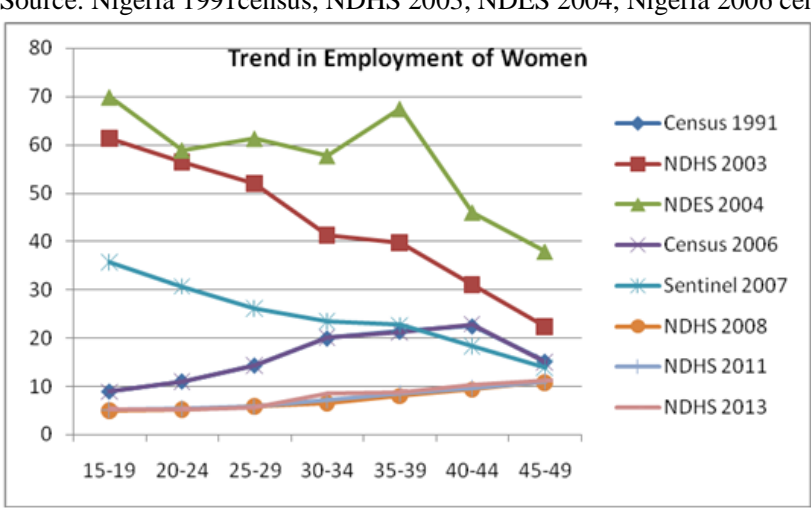

Figure 9. Trend and Level in Age-Sex Specific Employments for women, $1991-2013$

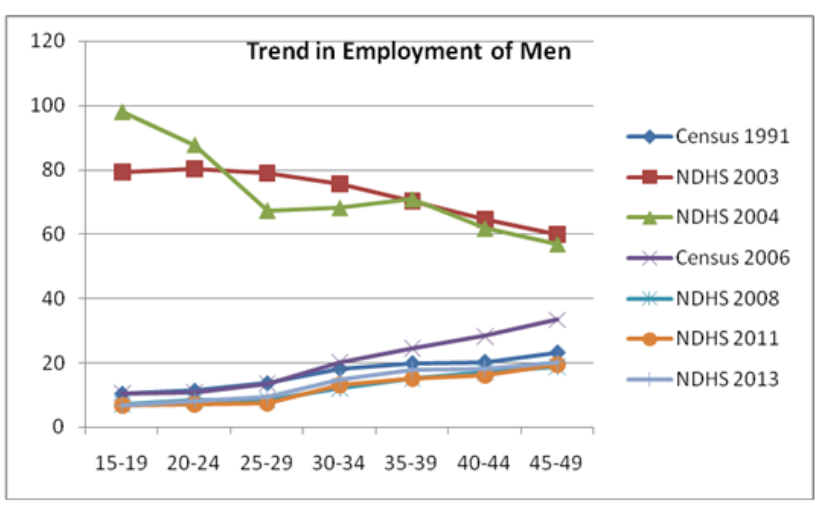

Figure 10. Trend and Level in Age-Sex Specific Employments for men, 1991-2013

Literacy is the ability of a person to both read and write, with understanding, a short simple statement on his everyday life. Table 2 shows the literacy rates of the surveys carried out in Nigeria by age and sex. The overall literacy rate in 1991 Nigeria census for the sexes combined is about 57 percent. The corresponding rate for the men is 66 percent while the rate for women (48\%) is below the national average. The rates are higher for men than for women in each age group. For 40 years and above, literacy rate is at least twice as high for men as for women. In NDHS 2003, the age specific literacy rate for men and women shows a similar pattern. Women are less likely than men to be able to read and write: 61 percent of women and 79 percent of men are literate. The gender gap in literacy decreases from older to younger cohorts with literacy rate among young adults aged 15-19 at 61 percent for women and 79 percent for men compared to literacy rates among older adults age 45-49 at 22 percent for women and 60 percent for men. The NDES Data survey, like the NDHS survey, assumes that respondents who have attended school beyond the primary level are literate, therefore, NDES 2004 indicates that age 15-19 years, 70 and 98 percent are for women and men respectively are literate while 38 and 57 percent of women and men respectively from $45-49$ years are literate.

The overall literacy rate according to their background characteristics (age, residence and region) indicates that 59 and 52 percent for men and women are literate. Also, from the sentinel survey 2007 for women, there is a similar pattern from age group 15-49 with NDHS 2003 survey for women. Even though, there is no data at hand for men, it is obvious that age specific literacy rates for men and women will still show a similar pattern as in NDHS 2003, that is, the literacy rates for men are higher than those for women. The literacy status of respondents in the 2008 NDHS shows that the pattern of men's literacy is similar to those of women. However, there is disparity that 40 percent men are literate compared with 13 percent of women. Among the population aged 15-19 and 45-49 years, 82-67 and 69-32 percent for men and women respectively are literate. Above 85 percent of urban males and 56 percent of urban females aged 30-34 years were literate. The corresponding literacy rate for the rural areas were 73 percent for males and 67 percent for the females 
which indicates the narrowing sex differentials in literacy levels among young generation albeit in favour of the male child (Data in 1991 census, Pg 126).

\section{Summary, Findings, Conclusion, and Recommendations}

\subsection{Summary and Findings}

This study from the outset indicated that economic planning will be difficult without the knowledge of women literacy, education and employment status as these are strong factors of population change. Since women population data are the major elements of economic planning, it is necessary to note that any error, has the potential of frustrating the economic plan. Therefore, the knowledge of population details such as literacy rate, education and employment of women goes a long way in enhancing economic planning, women empowerment and subsequent development it engenders. The results show that there is disparity between women and men education according to household economic status as in the poorest households, 40 percent of men are literate compared to 13 percent of women. The result is similar to the results obtained from variables like occupation, agriculture sectors, etc. in Nigeria.

Employment is one source of empowerment for women but unfortunately it is difficult to measure employment status because the informal sectors are not reported. However, the data on hand indicates, for instance, that women and men currently employed in the North West are 46 and 54 percent respectively. Apart from comparing the results to enable a good summary and findings to be made, charts were added. These show clearly that the number of educated women is low an obvious impediment to development planning. It is obvious that the men are dominating in the $\mathrm{s}$ of basic indices of human development examined by this study. The tremendous increase of women in Nigeria population depicts that the realization of the third millennium development goal which is women empowerment can hardly be achieved if nothing is done to improve their literacy rate, educational attainment and employment rate.

\subsection{Conclusion}

Considering the state of the Nigerian economy its need for development cannot be neglected and since it has been established that women play a vital role in national development, the role of women in the Nigerian economy cannot be ignored. In the light of the findings made, the following conclusion is made. They study discovered that efficiency of the women on the development and plan of the Nigeria economy are not yet felt because there is a big disparity between women and men with the ratio 1:3 in almost all the sectors. It is pertinent to note that women constitute a greater part of the Nigeria population and they can only be ignored at the peril of the economy. Acha (2014), population projection result shows that women population will grow exponentially and without commensurate growth in their literacy rates, education attainment and employment the vision 2020 development goal seems a mirage.

\subsection{Recommendations}

A role of development cannot be neglected in any nation so as the role of women in the Nigerian economy cannot be ignored. In the light of the findings made, the following recommendations are made:

i Government should allow women to contribute and participate fully in all aspects of life in Nigeria.

ii Nigeria should increase the literacy rates, education attainment and employment of women participation in education.

iii There is need for public enlightenment campaigns so as to get the women educated about the need for registration and other related events so that the women will co-operate with the data collection agencies to give rightful information.

\section{Reference}

[1] Acha, C. K. "Women empowerment as a measure of good governance in Nigeria", International Journal of Natural and Applied Sciences, 5 (2): 167-173, Jun. 2009.

[2] Aderant, I. A. "Situation Analysis of the Status of Women in Nigeria," Concept Publications, Lagos, Apr. 2002.

[3] Anderson, D., Vinnicombe, S., \& Singh, V, "Women only leadership development: A conundrum”. In K.T. James, \& J. Collins (Eds.), Leadership learning: Knowledge into action London, Palgrave Macmillan, 147-161, Apr. 2008.

[4] Annekova, V. "Global Approach to Fostering Development of Women Entrepreneurship”, FSA Contemporary Issues, IREX,. Jan. 2001.

[5] Arene, C. J. "Comparative economics of maize and rice production among resource-poor farmers in Anambra state of Nigeria”. African Development Review 4 (1): 102-13, Sep. 1992.

[6] Ayu, A. "The Teacher Factor in falling standard of Education in Nigeria” Farfaru Journal of Multi-Disciplinary studies, 1 (2) 235239, Jun. (1991).

[7] Ayu, H.I. "Women and Agriculture in Nigeria: An Analysis of Government Policies and Implementation of Programmes. Centre for Development Studies. University of Jos, 5 (3), Mar. 1992.

[8] Bilimoria, D., \& Liang, X. "Gender equity in science and engineering: Advancing change in higher education. New York, NY: Routledge. Jan. 2012.

[9] Burke, R. J. \& Major, D. A. "Gender in organizations: Are men allies or adversaries to women's career advancement? Northampton”, MA: Edward Elgar, May, 2014.

[10] Damilola Taiye Agbalajobi "Women's participation and the political process in Nigeria: Problems and prospects: Problems and prospects” African Journal of Political Science and International Relations, 4 (2), 075-082, Feb. 2010.

[11] Debebe, G. "Creating a safe environment for women's leadership transformation". Journal

[12] Debebe. G., \& Reinert, K.A. "Leading with our whole selves: A multiple identity approach to leadership development”. In M. Miville \& A. Ferguson (Eds.), Handbook on race-ethnicity and gender in psychology, 271-293, Nov. 2014. New York, NY: Springer.

[13] Ekundayo, A., \& Ama, B. "Nigerian Women and Political Participation: The Way Forward" International Journal of Educational Foundations and Management, 2 (1), 71-81, Mar. 2014.

[14] Ely, R. J., Ibarra, H., \& Kolb, D.M. "Taking gender into account: Theory and design for women's leadership programs”. Academy of Management Learning \& Education, 10, 474-493, Oct. 2011. Retrieved from: http://dx.doi.org/10.5465/amle.2010.0046

[15] Hopkins, M.M., O’Neil, D., Passarelli, A., \& Bilimoria, D. "Women's leadership development: Strategic practices for women in organizations". Consulting Psychology Journal: Practice and Research, 60, 348-365, 2008.

[16] Iheduru, N. G "Women Entrepreneurship and Development: The Gendering of Microfinance in Nigeria”, Paper Presented at the 8th International Interdisciplinary Congress on at Makeree University, Kampala-Uganda Women, p. 21-26, Mar, 2002. 
[17] Jarvis, C. Gulati, A., Mcririck, V., \& Simpson, P. "Leadership matters: Tensions in evaluating leadership development. Advances in Developing Human Resources, 15, 27-45, Jun. 2013.

[18] Lewis, P. "The Quest for Invisibility: Female Entrepreneurs and the Masculine Norm of Entrepreneurship", Gender Work and Organization, 13 (5): 453-469, Jul. 2006.

[19] Mansor, N., Women in Business: Determinants for Venturing in Malaysians SMEs, 2005. [Online]. Available: http://www.tbs.ubbc/uj.ro/studia/articol/volume4/number2/ [Accessed Nov. 1, 2014].

[20] Mazrui, A. "The Black Woman and the Problem of Gender: Trials, Triumphs and Challenges", Lagos Guardian Lecture series Publications, Lagos, Nigeria. 3 (2), 1-20, Jul. 1991.

[21] Nigeria Demographic and Education Survey (2004); from Nigeria demographic and health survey 2003. Abuja; National population commission

[22] Nigeria Demographic and Health Survey Abuja; National Population Commission, 2008.

[23] Nigeria Demographic and Health Survey. Abuja; National population commission 2003.

[24] Nigeria Demographic and Health Survey. Abuja; National population commission, 2011.
[25] Nigeria Demographic and Health Survey. Abuja; National population commission, 2013.

[26] Nigeria Population Census. Abuja; National Population Commission, 1991.

[27] Nigeria Population Census. Abuja; National Population Commission, 2006.

[28] Nigeria Sentinel Survey. Abuja; National Population Commission, 2007.

[29] of Management Education, 35, 679-712, Jun. 2011.

[30] [Online] Available: http://www.onlinenigeria.com/volume4/number2/Arene (1993) [Accessed Nov. 1, 2014].

[31] [Online] Available: http://www.onlinenigeria.com /volume4/number2/Wushish (1993) [Accessed Nov. 1, 2014].

[32] Peters, A.A. "Population and Human Resource Development in Nigeria”. A paper presented to Course 19 participants at the National Defence College, Abuja, 2010.

[33] Peters, A.A. "Population and Human Resource Development in Nigeria”. A paper presented to Course 20 participants at the National Defence College, Abuja, 2011. 